ARTICLE

DOI: $10.1057 /$ s41599-018-0077-9

\title{
A comparative study of the Belt and Road Initiative and the Marshall plan
}

\author{
Simon Shen ${ }^{1} \&$ Wilson Chan ${ }^{1}$
}

\begin{abstract}
Since the introduction of the Belt and Road Initiative (BRI) in 2013, both the mainstream media and professional analysts began to name the Initiative "China's Marshall Plan". While the rhetoric may simply be an eye-catching term constructed in journalist and consultancy circles, this paper examines the background and purposes behind these two grand projects in order to shed light on the similarities and the differences of their effects on the world order. By comparing the projects under five different aspects-boosting exports, exporting currency, countering a rival, fostering strategic divisions, and siphoning away diplomatic support-this paper argues that while the two projects may have similarities and aim to respond to the malfunctioning world order through macro political-economic investments and developmental aid, their outcomes (given the relative differences of the global position of rivalries-USSR in Marshall Plan; US in BRI) and the changing economic structures, could be very different. As a result, this paper concludes that it may be too early to suggest that the BRI could bring similar outcomes as the Marshall Plan, especially in competing for the global leadership in the 21 st century.
\end{abstract}

\footnotetext{
${ }^{1}$ Faculty of Social Science, The Chinese University of Hong Kong, Sha Tin, Hong Kong. Correspondence and requests for materials should be addressed to S.S. (email: simonshen@cuhk.edu.hk)
} 


\section{Introduction}

- he rhetoric of comparing China's Belt and Road Initiative (BRI) with the U.S. government's post-war Marshall Plan first became popular in 2014 (Chen, 2014a, b) and began to receive serious consideration around 2016, when it started to become viral on mainstream media and consulting spheres. Financial Times in 2015 described BRI with wordings "Like the Marshall Plan, the new Silk Road initiative looks designed to use economic treats as a way to address other vulnerabilities" (Financial Times, 2015). Kevin Sneader of McKinsey Hong Kong commented in an interview that "Some people have talked about this (BRI) being the second Marshall Plan... [and the Marshall Plan was merely]...one-twelfth the size of what is being contemplated in the One Belt, One Road initiative" (Ma, 2016). In the same year, BRI was referred to as "China's Marshall Plan" on Bloomberg (Curran, 2016) and described as the "Marshall Plan without a war" by analysts reported on South China Morning Post, 2017 (Sabine, 2017).

However, Many pro-China, liberal analysts partly disagreed with such comparison (Chen, 2014a). The first reason is the "global" scale of BRI should not be compared with the merely European Marshall Plan while the capital involved is also incomparable in size. The second reason is the theoretically "boundlessness" of BRI, contrary to the Western European, anti-Soviet "boundary" of Marshall Plan, though it might be confusing if we take into account the fact that the U.S. government did actually organize parallel aid programs to Asian states, too. For example, Japan and the then Nationalist government of China received aids no less than many European, Marshall Plan beneficiary countries, and their economic performances were arguably even more successful than some Western European countries today. Of course, we cannot compare dollar signs on proposals and oral promises of what will be done in BRI with what has already been achieved with successes and limitations already demonstrated in the history of Marshall Plan. Such discussions could easily turn into ideological debates that none could yet draw any rigorous, factual conclusions.

However, we can analyze the political economy and international relations background and original purposes of the Marshall Plan and compare to that of the BRI today. As we can see on the surface, both projects have interlocking political and economic agendas. Some say it is using economic means to solve political problems, while others say it is using political means to solve economic problems (Frieden, 2006). Nonetheless, there are five core similarities in the background and purposes of the Marshall Plan and BRI by their initiating countries, namely (1) boosting exports, (2) exporting currency, (3) countering a rival, (4) fostering strategic division, and (5) siphon away diplomatic support. These similarities will be discussed with a realist perspective in separate sections in this paper.

\section{Historical context of the Marshall plan and belt and road initiative}

Although there can always be a long list of political and economic causes that encouraged their specific policymakers to put forward these grand projects, the historical reasons for both BRI and the Marshall Plan to achieve necessary state, society and market support to be launched at particular times in history, are comparable. In short, both BRI and the Marshall Plan were adopted at times when the global system was dysfunctional. The liberal scholars call it global "market failure" or "disequilibrium"; The realist scholars call it a "global power vacuum" with "hegemonic opportunities". In this sense, the complete chaos in Europe after the two World Wars and the Global, or some say, "Western" Financial Crisis (2007) and its aftermath of prolonged global economic stagnation, are comparable.

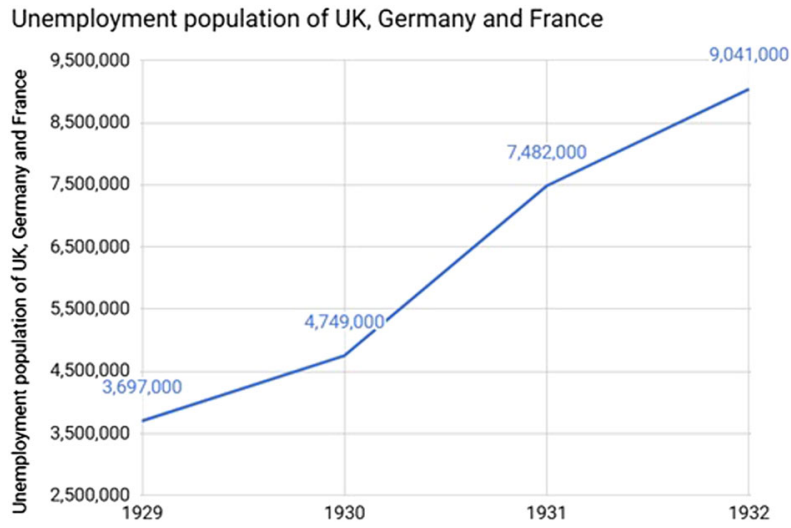

Fig. 1 Unemployment population of UK, Germany and France. Source: http://www.dhr.history.vt.edu/modules/eu/mod04_depression/ evidence_detail_03.html

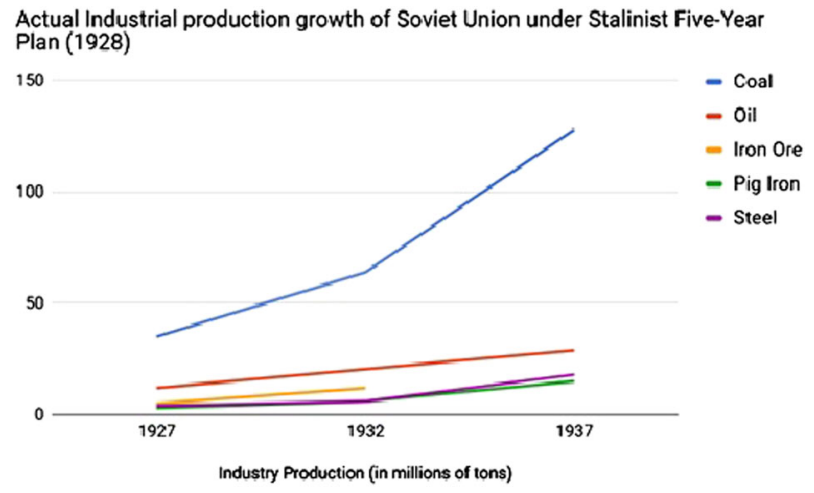

Fig. 2 Actual Industrial production growth of Soviet Union Stalinist FiveYear Plan (1928). Source: https://learning-ibhistory.wikispaces.com/file/ view/Stalin\%27s+Economic++1928-41.pdf

In much of the early half of the twentieth century, prosperity in the imperial age was fading in Europe. There were interlocking episodes of massive unemployment and total wars, both devastating to commoners and ruling classes alike in Europe. The classic capitalist system failed, both politically and economically. Things were especially worse at the beginning of the Great Depression. Unemployment had been soaring since 1928 with little signs of improvement all the way through the 1930s. All these prompted Europe to simply go into another World War (See Fig. 1). At the same time, the communists were gaining grounds. The Soviet Union went on rapid industrialization especially in heavy industries after the launch of Stalin's Five Year Plan in 1928 (See Fig. 2). Communism, in terms of economic performance and political ideals, was popular in 1945, despite its extremism in practice. The Marshall Plan was therefore built based on such socio-political background, aiming to save capitalism from being marginalized in the world system.

The Marshall Plan solved problems of 1945 but also created new problems for 2013. A post-war time frame (1945-1979) would view it as an economic success in large. The American financial aids were quickly circulated in markets and created a post-war economic boom in the Western world. The U.S. successfully exported U.S. dollar, turning it into a global currency, and ever since 1945, the majority of developed countries in the world had not clashed by military means with each other anymore (at the very least, there has yet to be a war with a casualty as high as the WW2-from 50 to 80 million) (Necrometrics, 2013). However, not getting into wars does not necessarily mean global problems are solved. 

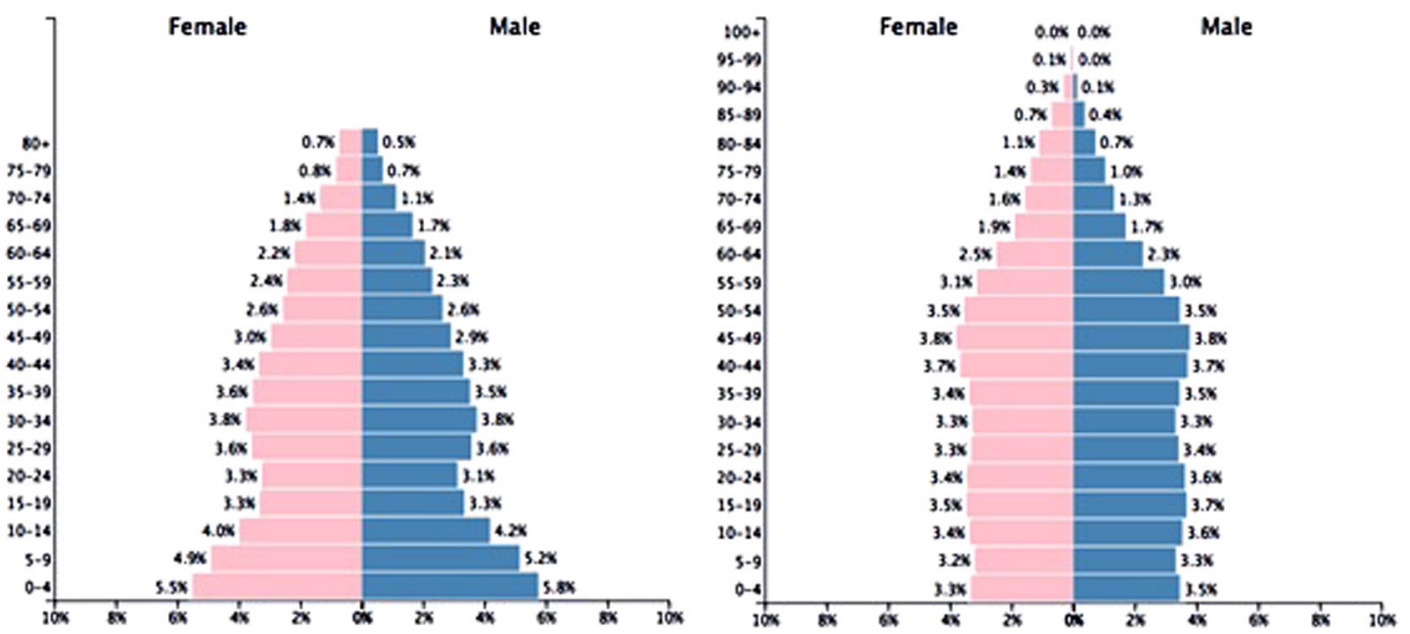

Fig. 3 Population Pyramid of U.S. in 1955 (left) and 2007 (right). Source: https://www.populationpyramid.net/united-states-of-america/

Economically, the Marshall Plan rebuilt a strong consumptionbased global economy cemented by the post-war baby boom in the West. The vibrant and large middle classes in Western countries created sustainable private consumption demands which provided less developed economies with opportunities to accumulate capital through exporting manufactured goods. The private consumption engine, however, is slowing down irreversibly due to the natural event of population aging of the baby-boomers in the West (See Fig. 3). The implications of the ageing population in the West are in twofold: first of all, unlike the younger generation who generally spends on high-end commodities and physical goods-the West is good at developing them and outsources to Chinese companies to produce them, the spending pattern of old-aged baby-boomers is different amongst themselves, from demanding more tailor-made services to increasing price-sensitivity toward ordinal goods (A.T. Kearney Inc., 2013; Best, 2015). Secondly, with the gradual diminishing labor force and the increasing reliance on retirement welfare, the potential further expansion of China's share on the global market may curtail as domestic consumption power structure changes fundamentally. Indeed, Atkinson earlier working paper has already projected the increasing income inequality, in both market and disposal income in developed countries (Atkinson, 2000). Subsequent research also confirms that the income inequality has become more salient after the financial crisis, though social transfer and policy could cushion the effect of unequal distribution (OECD, 2013). The widened inequality has limited government spending options as more resources are expected to be spent on social transfer rather than infrastructure, which further suppresses the comparative advantage of China in global trade.

In fact, the slowing of global real economic growth was largely patched by the liberalization of the financial sector, the "Big Bang" sudden deregulation of financial markets in the early 1980s. The U. S. somewhat maintained the Dollar's supremacy in the global economy, especially through the Petrodollar system in the global trade of oil. However, the Global Financial Crisis of 2007 and 2008 was the turning point in which the fall of the U.S.-led world order, or say the "Washington Consensus" (Centre for International Development at Harvard University, 2003) went into prolonged stagnation with a considerably large number of developing countries still struggling to accumulate capital for development through exports. The "Beijing Consensus", which was driven by infrastructure building, economic development and controlled economic (and political) liberalism, was introduced in Asia (Zhang, 2011). Further income inequality across the world not only requires government intervention with limited private resources available in the market, but also the gradual turn on trade protectionism-the rise of Donald Trump could be the best capture of such trend in the developed world. The belt and road Initiative, therefore, could be viewed as the policy tool to address the problems of the world system to-date, and China's own weak economic growth.

\section{Comparing the Marshall plan and Belt and Road Initiative- from economic to political purposes}

As explained above, there are certain circumstances in the background and purposes of the Marshall Plan that are comparable with China's belt and road initiative today. Comparisons are made according to the five themes (See Table 1).

Boosting exports. In the ending phase of World War II, the United States was a strong manufacturing country equipped with the world's top industrial capacity. However, the saturation of the domestic market and U.S.'s failure to export excess capacity caused economic growth to stagnate. In order to cope with the post-war economic transformation and the problem of overcapacity, the United States was forced to seek overseas markets for their products (Shen, 2016).

In fact, it is often argued that the U.S. and Soviet victory in World War II was mainly a result of both countries' extremely large heavy industrial capacities. In the year 1950, it was estimated that the United States accounted for $27.3 \%$ of the world's GDP (Groningen Growth and Development Center, 2014). The Soviet Union, being the first runner-up after the US, had a GDP approximately one-third of U.S.' size, while the other Western European countries below USSR, and the rest of the world were generally incomparable to this scale. The end of the war, on one hand, removed uncertainties for long-term investment, but the other side of the coin was a sharp reduction of manufacturing demand from war supplies and the risk of massive unemployment following peacetime reduction of military jobs. The same scenario was true in the interwar period when "the war to end all wars" (Reference.com, 2014) ended nothing, but brought the Great Depression and World War II. It was therefore necessary for the U.S. to channel capital into investing in war-torn regions, mostly in Europe and some in Asia to uphold economic sustainability, and hope that the quickly reconstructed Europe would generate new demand for American goods and services to recover from the fall due to the War and the end of the War.

The terms of the Marshall Plan stated that European countries being aided should accept U.S. investment and import U.S. goods. By providing aids to various countries, the United States simultaneously underwent an economic transformation (Shen, 2016). 


\section{Table 1 Comparison between Marshall plan and China's belt and road Initiative}

1) Boosting exports

Excess industrial capacity after the end of World War II and

declining military demands

2) Exporting currency

Replacing GBP as an even more influential global currency to Internationalization of RMB, a yet inconvertible, closed currency

foster global stability

3) Countering a rival

Hedging the growing influence of Soviet Union in Europe

4) Fostering strategic division

Ensure geopolitically important countries like Germany to be at

least not fully under Soviet rule

5) Siphon away diplomatic support

Offering aids to Soviet satellite states, e.g., Yugoslavia
Excess industrial capacity after the 2008-2009 Chinese economic stimulus plan and declining Western consumption demands

Hedging U.S. control of essential trade routes and energy supplies

Dividing existing organizations like APEC by providing infrastructure to member states which are dire in need

AIIB to involve major EU members, e.g., Central Europe "V4"

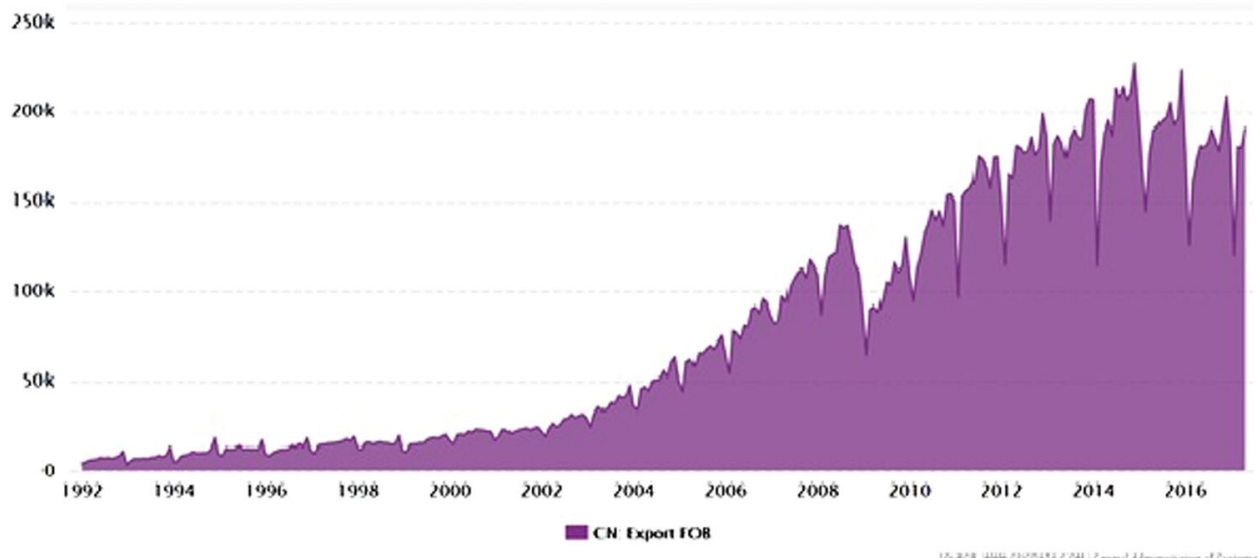

Fig. 4 Value of China export by US dollar-Falling since 2014. Source: General Administration of Customs (http://www.cdcdata.com)

China faced a similar situation in the aftermath of the Global Financial Crisis (2007-2008). After its outbreak, it was obvious that the West was in economic stagnation and China's export-led growth was no longer sustainable. After another dramatic decade of boosting the construction of domestic infrastructure, China still faces heavy industrial overcapacity that requires external markets to quickly absorb. BRI points to both the mature European market and also the Central and South Asian trade routes that consist of underdeveloped countries providing opportunities for Chinese infrastructural exports (See Fig. 4).

As discussed above, a structural reason behind such chronic stagnation in export demand might be population aging. With a majority of the population leaning towards retirement in these developed countries, it is not difficult to foresee that consumption growth would be weak, if not declining. Almost a decade after the Global Financial Crisis, it has become obvious that the weak demand in the West for traditional goods and commodities, which China as a "world factory" exported most, is a new norm rather than an unfortunate accident. It is therefore obvious that China should look out of the box for new growth engines.

Although powerful monetary actions, like Quantitative easing (QE), are taken to counter this stagnation, they are usually not very effective in boosting the post-crisis economy. Most major Western countries have tried hard to channel capital into real economy to improve gross demand, mainly through promoting technological "start-up" companies. However, very few are really commercially profitable, and even many of the extremely well-performing "unicorns" are actually suffering losses, unhelpful in revitalizing growth in real economy (Financial Times, 2015) (See Table 2).
Table 2 Weak profitability of some major "unicorns" listed technological start-ups

\begin{tabular}{llll|}
$\begin{array}{l}\text { “Unicorn" start-up } \\
\text { company }\end{array}$ & Revenue (US\$) & Net profit (US\$) & Date \\
\hline Snapchat & $\$ 3.1 \mathrm{~m}$ & $-\$ 128.5 \mathrm{~m}$ & Jan-Nov \\
& & & 2014 \\
Uber & $\$ 104 \mathrm{~m}$ & $-\$ 56 \mathrm{~m}$ & 2013 \\
& $\$ 56 \mathrm{~m}$ & $-\$ 109 \mathrm{~m}$ & $\mathrm{Q} 22014$ \\
Lyft & $\$ 26.30 \mathrm{~m}$ & $-\$ 124 \mathrm{~m}$ & $\mathrm{Q} 32015$ \\
\hline Source: https://www.cbinsights.com/blog/leaked-unicorn-financials/ & \\
\hline
\end{tabular}

Given these pessimistic facts, it is more than obvious that the export boom in the traditional Western developed world market since the postwar era will not repeat itself anymore. In fact, China has tried to artificially boost the local economy through radical increases in investments, like what the U.S. had done to support Europe in the Marshall Plan. However, it is not delivering the strong consumption as output like what happened in late 1950s Europe.

The completion and expected completion of these numerous domestic infrastructure investment projects since 2007 have left China with considerably good quantity and high value-adding, infrastructure-building capacities. However, China's economy still has a long way to go in terms of its progress in transforming into a conventional kind of developed, consumption-based economic structure. The immediate export of such "overcapacity" 
is therefore necessary to prevent China from walking into another inter-war styled economic crisis. As fate would have it, the strength of China's manufacturing industry is infrastructure building, and Central and Southeast Asia lack investment in the field of infrastructure. Therefore, China oversaw the establishment of the Asian Infrastructure Investment Bank (AIIB) in accordance with the belt and road initiative in order to promote "Made in China" in Central and Southeast Asia (Shen, 2016).

Exporting currency. The Marshall Plan allowed the United States to export its currency. The total amount of aid provided was US $\$ 13$ billion, which is now equivalent to roughly $\$ 100$ billion. The U.S. dollar was used for subsidies, while European countries purchased U.S. goods with their own currencies. Over time, the U.S. dollar has become a tool for stability; the "Money Credit" provided by the plan created a basis for future frequent quantitative easing (Ibid.).

Since the beginning of World War I, there was a power vacuum for a reliable global currency to support international trade and to establish a solid platform for the world system to function on. By the end of World War II, there were discussions of reinstalling the UK as the backbone of the post-war global economic system, and GBP as a convertible global trade currency again. However, this was not feasible anymore due to the rapid decline of the British Empire and severe indebtedness of Britain due to the two World Wars.

The U.S. dollar, the only major "hard" currency in the world at the time that was adequately backed by gold, was promoted to be the world currency and stabilizing anchor of European currencies as in the Bretton Woods system. Back in 1945, it was agreed without much objections from the diversified Western European states. They were a list of severely war-torn countries back then, and none had the capacity or attention to tackle anything on top of their own reconstruction. The U.S. was then a relatively established global military power that could guarantee that different countries would act and respond to cross-border trade and investments predictably. Consensus was quickly reached and the influence of U.S. currency remained until today.

The same is wished by Chinese economists. Today, China is also seeking to increase the international use of its currency. The International Monetary Fund recently included China's renminbi $(\mathrm{RMB})$ in its Special Drawing Rights basket of currencies. However, the most effective way to promote cross-border circulation of the RMB is still regional economic cooperation. The RMB is regarded as the strongest currency among the major regions of the belt and road initiative. Though the details of the policy have not been decided, a significant number of Chinese specialists state that the RMB should be used as the settlement currency of large-scale commodity trade in the region. At the same time, the engagement of Chinese capital investment in infrastructure building should be increased and cross-border payments by RMB (Ibid.) would be promoted.

This sort of "currency war" theory believes that the internationalization of the RMB through BRI would allow China to challenge the United States' leading role in the international arena, just as the status of the U.S. currency was consolidated through Marshall Plan (Ibid.). However, this is much more difficult to achieve in the highly developed, re-globalized world today than in the war-torn 1945. RMB to-date is still not an internationally convertible currency and China is, in many senses, strengthening, instead of liberalizing, capital control in recent years. However, we can still compare the purposes behind attempts to export currency in BRI and Marshall Plan. In face of such uphill situation, China adopted the tactic of reaching out to former Soviet Union countries first because they are understandably less entrenched in the existing world system.
The first step is to cooperate with Central Asian countries including Kazakhstan, Kyrgyzstan, Tajikistan, Uzbekistan and Turkmenistan. These are all former Soviet countries with a relatively negative reputation in governance to international investors which also means they are less associated with the West. Negotiations are quite smooth, too, with Central European countries, the "Visegrad Four" (HKTDC, 2017)—Czech Republic, Hungary, Poland and Slovakia. These four countries are also former Soviet countries but have undergone westernization in the 1990s and are new members of the European Union. On the other side of the belt and road Initiative, the Maritime Silk Road Initiative (MSRI) has much slower progress and seen fewer news. The reason for this is rather simple-many of the MSRI countries are former colonies of European empires with remaining economic ties with the Western, global economic system after independence. Therefore, it is understandable that they are harder to be convinced into closing deals with BRI and less welcoming towards the idea of adopting RMB as the settlement currency.

Countering a rival. The United States hoped to use the Marshall Plan to revive war-torn Western Europe in order to demonstrate the superiority of capitalism over communism and undermine the influence of the Soviet Union. The instability of the European community favored the growth of communism; the Communist Party in countries such as Italy received strong support (Shen, 2016).

Back in 1945, communism was in rapid escalation, both as a military threat and also a representation of a seemingly quite possible alternative to global capitalism which failed catastrophically in much of the first half of 20th century since the outbreak of World War I in 1914.

To begin with, the War in Europe was literally a Soviet victory. From a European perspective, the European theater of World War II was in the large part fought by the Red Army. The USSR took up much work and casualty in defending against and later counter-attacking Nazi Germany to eventually conquered Berlin. Suggested by the research conducted by Boog et al., the Soviets mobilized 34 million troops with 12 million of casualties at the Eastern front (Glantz, 2005) against 7.8 million Nazis at the eastern front (Jodl, 1944) (4 million deaths), while American troops sustained 413 thousand casualties against a defending Nazi force of merely 2 million troops ${ }^{1}$ (with 340 thousand deaths) (Overmans, 2000).

Living standards of typical European people were more primitive than we could imagine today, too, not to mention the Great Depression and political turmoil in Western Europe would mean that in 1945, the majority working class people had never experienced working, living and building families in Europe prior to the outbreak of World War I. The commoners at that time had never seen a proper, functioning capitalist economic system in his/her entire adulthood. And the communists were demonstrating an alternative just around the corner.

Left-wing ideas were popular back then with the Soviet Union appearing as one, if not the only one, successful model of an industrialized economy since the rapid breakdown of Western Europe during the First World War and Great Depression. Although the popularity of Communism in Western Europe then is unimaginable today, the Left-wing governing paradigm is still visible in the enduring welfare states and their outrageously high government indebtedness, partly due to their inability to curb welfare spendings today.

Marshall believed that Western Europe was the key for an effective balance of power between the Soviet Union and the United States. If the European economy declined, the traditional capitalist world economic structure of the United States, Europe, and Southeast Asia could not be sustained. Therefore, providing 
long term and short term subsidies, as well as lowering trade barriers in Western Europe was essential to defend against communism and the Soviet Union (Shen, 2016).

The Marshall Plan provided a blueprint for undermining the influence of the Soviet Union. Similarly, China's BRI targets the United States as a potential competitor. The emphasis on interconnection stresses the construction of onshore energy pipelines, as well as harbors. By importing energy through dispersed channels, China can lower the strategic risk of energy imports and enhance control over Indian Ocean shipping routes. At the same time, the consolidation of trade relationships among China (with its exports of manufactured goods), the Middle East and Central Asia (energy exports) and Southeast Asia (exports of raw material) can counterbalance the rebalancing strategy of United States and reduce the economic dependence of China on the U.S. (Ibid.).

However, as described by Ted Galen Carpenter, China is a "prickly but pragmatic" power in her relations with the United States (Carpenter, 2013). The introduction of the vague "new type of great power relations" on one hand focuses on developing a cooperative China-US partnership based on the fundamental interests of China and U.S., as well as the world, while on the other hand aims to redefine the China-US relations with some Chinese characteristics (Zeng, 2016). From the Chinese perspective, the general conclusion on contemporary China-US relations is twofolded: on one hand, China acknowledges the fact that the United States, even after the Global Financial Crisis, will remain a superpower for years, thus a no-confrontational approach should be maintained as the core of Chinese foreign policy towards the United States; on the other hand as a rising power, China should proactively project her core interests in the Asia-Pacific, as the region itself is "big enough for both China and the United States", hinting that-at least in Asia-Pacific region-Beijing demands some sort of great power equality from Washington (Ibid.; Aberg, 2014; Chen, 2014a, b).

The belt and road Initiative, therefore, may serve as the best policy demonstration on this "new type of great power relations" in the Asia-Pacific region. Barston has long ago suggested that Chinese diplomacy nowadays could be best characterized by "centering rapid logistic expansion, accelerated information skill transfer arrangements, intelligence and market access" and it is carried through overseas visits, and subsequent investment by Chinese business, city and port delegations, rather than a highprofile leadership visit and bilateral summits (Barston, 2006). The merit of the belt and road Initiative focuses on economic initiatives, infrastructural building and interconnectivity along the belt and road countries, which could potentially benefit the United States as well. Taking the case of China-Pakistan Economic Corridor as an example, in order to protect Chinese companies and investment over the region, Beijing may have to work with the United States to tackle the terrorist groups in Pakistan or Afghanistan, which largely reduces American sole burden since the Global War on Terror. The apparent infrastructure-driven and civilian-driven approach also makes the United States very difficult to step-in and intervene, as neither the government nor the companies are capable or willing to invest such amount of capital in these risky countries. It is also difficult for Washington to challenge the narratives of the BRI as the policy, at least on its face, looks to create a win-win situation for all parties in the region.

Conversely, China's investment in some specific countries like Myanmar, Pakistan and Sri Lanka, with the specific focus on port facilities, energy infrastructure and transportation, will surely challenge the global presence of American sea power and help China protect their sea lane of communication. Indeed, strategists like Virginia Marantidou and Abhijit Singh have highlighted the belt and road Initiatives as a strategy to build "places with Chinese characteristics" through economic investment and "unconditional" loans (Marantidou, 2014; Singh, 2015). Given the conditions of the developing countries, China's BRI is somehow more attractive than condition-attached loans from the Washington Consensus' institutions. The BRI therefore provides an opportunity for Beijing to slowly replace American influence over the region, without really provoking the United States.

Fostering strategic division. In the post-World War II era, the United States wanted to incorporate all of Germany (not only West Germany) into the capitalist camp. If this could not be accomplished in the short-term, the United States had to ensure a prolonged division in Germany in order to prevent the whole country from entering the Soviet Union's camp. The U.S. emphasis on Germany was rooted in the high geopolitical strategic significance of Germany. Germany is home to Ruhr, a large industrial area that provided the essential natural resources (such as coal) and industrial capacity for the revival of the European economy (Shen, 2016).

Also, Germany is located at the intersection point between Eastern and Western Europe; allowing the Soviet Union to control Germany would obstruct the balance of power in Europe. In order to prevent the geopolitical risk of a possible Soviet Union-Germany coalition, the Marshall Plan strengthened political and economic ties between West Germany and Western Europe. The unification of Germany has been viewed as the key to ending the Cold War and bringing down the Iron Curtain.

Strategically, the struggle for control over Ruhr and the line of coal and industrial bases along the border between France and Germany was the source of most of the conflicts since the beginning of the industrial age and the two World Wars that eventually destroyed the pre-war world system. European Coal and Steel Community (ECSC) was immediately established after the end of World War II to operate above narrow national interests of various industrial powers. From one lense this was to prevent any future military conflicts between France and Germany, which we can see today is arguably successful. For example, in 2016, the French Army purchased its standard-issue rifle abroad and from her century-old military rival-Germany (De Larrinage, 2016) for the first time in modern history. From a Cold War perspective, the ECSC has successfully entrenched West Germany into the capitalist Western European bloc by gluing the governance and profitability of their industrial economic powerhouses to that of France, Italy and other Western European countries. Subsequent economic unions like General Agreement on Tariffs and Trade (GATT) were all achieved upon the foundation of ECSC.

It is reminded such division and boundaries shall not be viewed as a purely economic matter. After the collapse of Soviet Union, many of the former Warsaw Pact countries like Poland and Ukraine were enthusiastic about developing closer ties to, if not joining officially, the European Union for economic subsidies and market access for growth. However, this will inevitably link to membership or closer cooperation with the North Atlantic Treaty Organization (NATO) whose main purpose was, and still is, to contain Russia through military means. Such Western "encroachment" could have been one of the many reasons behind recent Russian aggression towards Georgia and Ukraine in order to rebuild buffers between Russia and the West. In a time of vicious economic sanctions between Russia and the European Union, BRI presents China as an alternative to making the hard choice of taking a side between the two.

As stated above, the Marshall Plan can be viewed as a factor that contributed to the division of West and East Germany. Similarly, BRI may lower the solidarity of Asia-Pacific integration organizations headed by the United States and Japan, such as 
APEC. By searching out APEC member states which desperately need infrastructure, BRI allows China to foster bilateral integration with those member states. That, in turn, will undermine the significance of APEC and delay these states' entry in the U.S.-led Trans-Pacific Partnership. Although those countries will still keep diplomatic ties with the United States, BRI limits the chance of the formation of coalitions against China, such as the U.S.-India and U.S.-South Korea coalitions in the past (Shen, 2016).

In Europe, China has also seen concrete progress in increasing trade with the "Visegrad Four" (V4) Central European, former Soviet satellites, currently European Union states. For example, Poland, with the advantage of coastal ports, has expanded the export of processed food via Eurasian rail lines; Hungary was the first European country to sign a BRI memorandum of understanding with China. At the same time, major Chinese automobile manufacturer BYD is going to establish the first fully-owned bus factory in Hungary; Foxconn is establishing logistic centers in the Czech Republic; in Slovakia, He-Steel Group of China, the world's second-largest steelmaker, recently closed an acquisition deal with the country's largest steel mill in Košice (See Fig. 5).

Seeing central Europe as a hub of the Asia-European trade network, China has been investing in logistical and transportation infrastructure in the region, mirroring the mass outflow of American infrastructural investment in the course of post-war reconstruction. As the first cargo train arrived at Lodz half a globe away from Chengdu, China Railway Rolling Stock Corporation is reported to be in the process of purchasing Škoda Transportation, the largest manufacturer of railway locomotive of Central Europe (Willoughby, 2017). Another pet project of BRI would be the Belgrade-Budapest High-Speed Rail Line. Under international spotlight and the scrutiny of Brussels, China had signed an agreement with Serbia to modernize its national railway, injecting $\$ 319$ millions in the process (Railway Gazette, 2016).

Siphon away diplomatic support. Another purpose of the Marshall Plan was to target countries in Eastern Europe with the aim of getting their support. Although Eastern European satellite states were not the primary targets of the Marshall Plan, the United States still provided aid for those countries if they abandoned the communist model. Tito's Yugoslavia was an example of an Eastern European state that benefitted by accepting

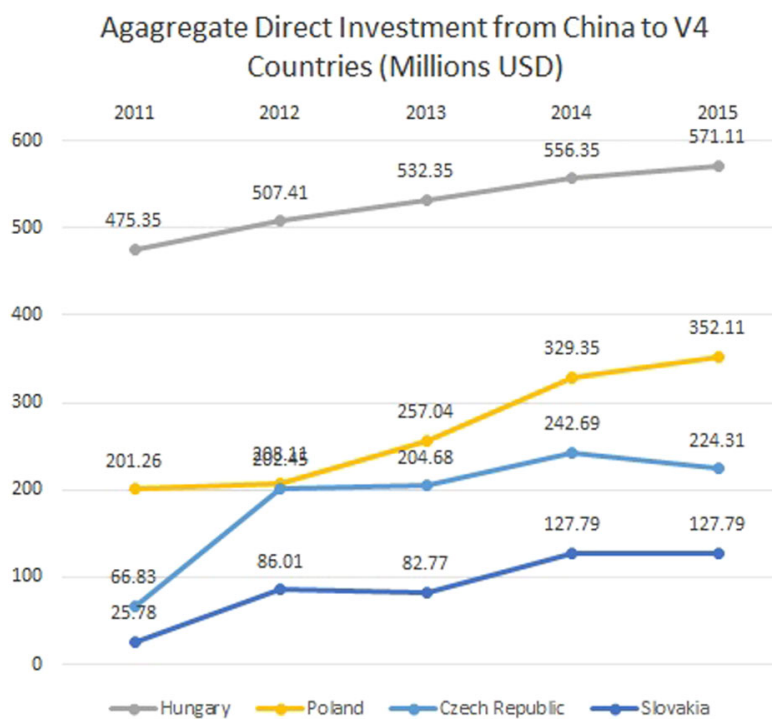

Fig. 5 Rapid growth in direct investment amounts from China to V4 states. Source: http://www.radio.cz/en/section/business/chinese-trains-giantcrrc-to-buy-problem-hit-skoda-transportation
Marshall Plan aid. In other words, the United States hoped to use the economic development of Western Europe to showcase her superiority and provide incentives that could increase U.S. influence in Eastern Europe (Shen, 2016).

Today, the endpoint of BRI is located in Europe. It shows that China wishes to intensify relations with traditional U.S. allies in Western Europe, which in turn undermines U.S. influence in the region. Recent frequent interactions between the leaders of China and major Western European countries, as well as decisions by the U.K., France, and Germany to join AIIB despite the objections of Washington, seems to indicate the decline of U.S. influence. If economic and strategic integration is achieved between Asia and Europe, China may become the center of the world, leaving the United State marginalized.

Weak economic growth in the West, as mentioned above, provided the basis to shake the American "hegemony". Traditional liberal values, as coined by the "Washington Consensus" (Williamson, 2002). and established since the Marshall Plan, are losing light due to the disappointing economic performance and political correctness. Although China's "economic legitimacy", or say, its economic growth in the past 30 years, is still relatively weak when compared to post-war Japan and the "Four Little Dragons" of East Asia while the world still expresses concerns ranging from human right abusing to pollution, at least China is still an engine of economic growth and development. This is especially important to less developed countries which are thirsty to import growth while the West is expected to stay stagnant in the foreseeable future.

This explains why China employed fewer ideological justifications to BRI than the U.S. did when it launched the Marshall Plan. But still, the failure of the West in revitalizing economic growth is eroding support from the existing American-led global economic system which creates a gap that BRI may fill in.

This point exposes the main difference, or say the main advantage China has in promoting BRI than the U.S. promoting the Marshall Plan in 1945-1948. Back then, the U.S. was promoting a plan against a popular, rising, recently victorious political enemy while China today is promoting its plan against a structurally declining hegemony.

Creating new economic dominance?. While the abovementioned themes of comparison shed light between the operational motivations of Marshall Plan and belt and road Initiative, the macroimplications of the two plans shall also be discussed, i.e., the belt and road Initiative as a systematic innovation towards the current economic and geopolitical dominance. World System Theorists such as Giovanni Arrighi, Immanuel Wallenstein, George Modelski and William R. Thompson have related hegemonic positions of "great powers" in world politics to their extensive technological and commercial pre-eminence (Arrighi, 1994; Modelski, 1987; Modelski and Thompson, 1996; Thompson, 2001; Wallerstein, 1984). For instance, in analyzing "the long twentieth century", Giovanni Arrighi suggested the American replacement of British global leadership was to accumulate huge war credits during the WWI and WWII through long-time isolationism, and only started to engage international affairs when the world required the United States to represent a perceived general interest of "leading the inter-state system towards the restoration of principles, norms and rules of the Westphalia System" (Arrighi, 1994). Furthering the British "free-trade imperialism", the United States constructed, along the Marshall Plan to restore the order of Europe, the Bretton Woods institutions, the GATT and the dollar system for international trade, i.e., the Washington Consensus. The Marshall Plan, as an economic and social initiative, created a huge global economic and political market for the United States to shape the world order and consolidate her own image as the 
leader of the capitalist world. In terms of systematic innovation, George Modelski and William Thompson suggested that the exclusive dominance of fiber replacement such as plastics and synthetics produced in the United States, and the exclusive scientific-military-industrial products such as electronics and aerospace technology defined the transitions from British cottontextile order to American economic dominance until the 1970s (Modelski and Thompson, 1996), and the United States domination continues with the financial liberalization and telecommunication as systematic innovation. The Marshall Plan, which allowed European countries to purchase American goods and technologies, becomes an important motor to slowly replace British dominance in commodities and industrial technologies.

The belt and road Initiative, to some extent, could be viewed as the same token for China to slowly replace American dominance, especially if we take the rise of the more socialist Chinese economic model as a Polanyi-type of "Pendulum Swing" response at the global level (Polanyi, 1944). While Karl Polanyi's idea on transformation firstly applied to the individual nation-state, the global capitalist system constructed by the United States after the Marshall Plan may possibly induce a "global double movement" as a response. It is not a new story of Beijing consensus as a counteracting force against Washington Consensus, and the developmental model of China as a counter-model for free market capitalism. Even though Chinese government emphasizes that Beijing will never export her development model, the belt and road Initiative, which put emphasis on infrastructure-driven economy, is the partial success story of China's rapid modernization. Especially after the liberalization of service and financial sector after the 1970s, the infrastructure-based economy, no-string attachment loans together with pragmatism economic nationalism become viable alternatives proposed by Beijing to developing economies. While it may be difficult to say it is a systematic innovation-which is a crucial differentiation between Marshall Plan from belt and road Initiative which will be addressed in the later section, the belt and road Initiative could be viewed as a potential strategic plot from Beijing to slowly take over the economic order. Indeed, the investment on seaport related facilities in the Indian Ocean and along the African and Southeast Asian coastal area under the Maritime Silk Road initiative could always be viewed as a competition on the control of longitudinal inheritance of systematic lineage on the command of the sea from Jaffa to Colombo, and Hong Kong, adding the geopolitical implication of the belt and road Initiative (Harkavy, 2007; Thompson, 2001).

\section{Difference circumstances 1945 and today}

Undoubtedly, BRI does not emphasize on ideological factors as heavily as the Marshall Plan did in 1948. On the contrary, economic and financial considerations have been major concerns for China's initiative. Therefore, officials and some scholars in China state that the two strategies are not comparable. However, the highly globalized modern world does not view ideology as a major battlefield. Instead, major powers stress the importance of leading institutions and setting discourse within the global economic structure which the BRI is hiddenly working with such narration building exercise (Shen, 2016).

Apart from the difference in the importance of ideological matters, the world BRI advocates in front of today is not after an immediate complete destruction like the end of World War II in 1945. Economically, the world today has the U.S. dollar as an effective backbone currency, and international trade is times more sophisticated, economies more interdependent than in the imperial age in a sense that most economies today will not be able to feed their populations by subsistence anymore. It should also be noted that even though US contribution on global GDP dropped drastically from the period of 1940s-1960s when the U. S. commanded more than $40 \%$ of the GDP contribution to the world, to the $24 \%$ in 2015 , two years after Xi announced the belt and road Initiatives, the U.S. still enjoyed a rather comfortable lead in terms of overall GDP contribution to the world, as China GDP contribution to the world is $14.84 \%$ in 2015 (Kennedy, 1987; Patton, 2016). In terms of GDP per capita, while the growth of China is remarkable throughout the last 50 years, the per capita GDP was just one-seventh of that of United States. ${ }^{2}$ Given the rather huge gap in terms of global GDP contribution and GDP per capita, whether the belt and road Initiative could perform a similar economic function of the Marshall Plan, i.e., consolidated U.S. economic leadership, is still in doubt-though it is also too early to conclude owing to the duration of BRI is actually only 4 years from its announcement.

Politically, the world has much more inclusive international organizations than in 1945. U.S. military supremacy is incomparable with the fairly distributed range of sporadic European powers, with an annual military expenditure these days higher than the 2-9th largest expenditure states combined, as shown by the research conducted by SIPRI (SIPRI, 2017). While one merit of Marshall Plan is to transform U.S. economic dominance into "economic defense" and "social defense" against the communist rivalries through massive economic and social investment directly from United States to the rest of the capitalist world, such economic and social defense is at doubt in the case of belt and road Initiative. A recent report from the Asian Development Bank reveals that even though two new multilateral banks, namely Asian Infrastructure Investment Bank (AIIB) and New Development Bank (NDB) were established and in operation, the estimated infrastructure investment gap in developing economies-the key allies that the belt and road Initiative wishes to target-is $\$ 330$ billion (1.7\% of total GDP) to $\$ 459$ billion (2.4\% of total GDP) (Asian Development Bank, 2017), a gap that China could never solely fill up and would require private investment (Ibid; He, 2017). Indeed, the $\mathrm{ADB}$ report also reveals that China has left herself a $\$ 68$ billion ( $0.5 \%$ of GDP) to $\$ 151$ billion (1.2\% of GDP) investment gap to be filled and some fundings from AIIB and NDB are used to finance China's infrastructure project (Asian Development Bank, 2017). With limited funds available from the Chinese government, the infrastructure investment-driven belt and road Initiative may have a risk of defection or even economic backfire as some scholars projected, or have to rely on private funding from the East, as well as the West (Ansar et al., 2016; He, 2017).

Optimists for investing in infrastructures of the very remote virgin lands governed by Central Asian countries may want to rethink, too. They are not war-torn countries, nothing like postwar Western Europe. The reasons why they are still in primitive developmental stages, 70 years after World War II and almost 30 years after the Soviet collapse, is widely overlooked. This is not a difficult question if we investigate more deeply into the political economies of these underdeveloped countries.

It is generally agreed that Central Asia has extremely high development potentials due to its current state of backwardness. Their relatively underdeveloped status in infrastructure provides China with a lot of opportunities via BRI to invest, export overcapacities, accelerate economic reform and to prevent recession. However, international investors have been reluctant to invest in these countries in the past decades because it is extremely risky to do so. Two main reasons behind are:

(1) Basically, all Central Asian countries are former communist satellites. After the collapse of the Soviet Union, they became a group of politically unstable countries, many of which were ruled by former Soviet leaders, such as Uzbekistan's first president Islam Abdul Ghaniyevich 
Karimov. He was the first president of Uzbekistan, and before that served as the first secretary of the Communist Party of Uzbekistan during the period of the Soviet Socialist Republic, for 27 years. The instability of these totalitarian regimes has always been a source of concern. In 2014, the "failed state index" by US Foreign Policy Magazine and the Peace Foundation concluded that the stability of these Central Asian countries was worrying, with Uzbekistan ranking the worst in the region. Many commented that these countries, though with great potential in the development of hard infrastructure, lack reliable governance protection. The local government's unproductive intervention in the market, the lack of a profound monetary system and corruption issues limits the level of protection to public and private investors, resulting in prolonged underinvestment and the backwardness we see today.

(2) According to the United Nation's Trade and Development Report 2009, many Central Asian countries were already heavily in debt before the Global Financial Crisis. With the recent trend of falling oil prices, their ability to repay debts is seriously questionable. In other words, if China and other institutes finance large-scale infrastructures, they will be bearing much higher risks than the U.S. did for Western Europe in 1948.

While on the other hand, what might make China easier in introducing BRI is that the rival (U.S.) in this case is declining, at least economically. The "rival" of China, namely the U.S. and her Western European allies, are still suffering from economic stagnation or decline since the outbreak of the Global Financial Crisis 10 years ago-when starting and ending a World War only took six years in total. This is obviously the opposite of the Soviet rise in 1945 as explained above. Although the world today is entrenched in a much better inter-connected world system than that of Marshall Plan times, the world today has widespread pessimism towards a deem economic future that the West has already seen symptoms of translating it into political disappointment and the emergence and the thrive of unconventional ideas, most iconic the Brexit in U.K. and the presidency of Donald Trump in the U.S.

For long-term investment projects of any kind, the perceptions of the future matters more than the past or present. This explains why China has employed a liberal, "brave new world" political marketing strategy for BRI instead of Marshall's confrontational "Soviet threat" strategy.

\section{Conclusion}

It will always be inaccurate if we compare the contents of what has already been achieved and well-recorded in the history of Marshall Plan with what has just been suggested and proposed in the prospect of belt and road initiative. However, it is still meaningful to compare the political and economic background and purposes behind the two grand development projects. Should that be called "market failure" or "global power vacuum", both the Marshall Plan (1948) and BRI (2013) were being put forward at times when the world system was not functioning properly. For Marshall, it was the two World Wars and the Great Depression in an era which completely destroyed the lives of two generations of Europeans with the growing threat of communism from Russia; for BRI, it is the prolonged global economic stagnation especially since the 2007 Global Financial Crisis. Both U. S. and China at their specific times designed their packages in ways that will simultaneously improve their leadership statuses globally.

The first purpose is to boost exports. Both the 1945 U.S. and the 2013 China are global leading industrial economies with problems of overcapacity and weak demands in global markets, therefore they want to step in to invest in other countries to create export demands. The second is to export their currency as the settlement currency for trade so as to "internationalize" and broaden the sphere of influence by financial structures. The third reason is to use these economic means to counter a rival. To Marshall, that was the Soviet Union and communism which was on rapid rise in Europe given the facts that they had made certain progress in industrialization while Western Europe was suffering Great Depression and the Soviet Union's victorious moral height from deploying superior quantity of armament and machines during World War II that eventually conquered Berlin and scored victory in Europe. The fourth reason is to foster strategic division by ensuring the periphery will at least not join the rival camp completely. Marshall offered generous support to West Germany to avoid the complete fall of Germany to the Soviet Union for this reason, while China offered infrastructural aids to APEC states to slowly attract them to support Chinese standards of free trade stimulated by the potential RCEP. The fifth reason is to siphon away diplomatic support. Marshall offered aid options to Soviet-controlled Eastern European states in an attempt to convince them to leave the rival camp, with Yugoslavia as one successful example. BRI is trying to do the same but with much more difficulties since most of the world is entrenched in the existing world system instead of being in prolonged complete chaos like the first half of 20th century. Therefore we can see that China's early BRI diplomatic successes are clustered with former Soviet countries in Central Asia and Central Europe because they are relatively less committed to the U.S. led superstructure.

The core difference one shall remember when comparing these two plans is that when the U.S. pushed forward the Marshall Plan, she was facing a world in complete chaos with a rising rival with some proven industrial and military capabilities over the immediate past 20 years. China's BRI is, however, facing a wellentrenched world system but in an era of prolonged stagnation and in some aspects, slow and gradual decline, with the main rival (U.S.) not in rapid status rise.

It should also be noted that even though the belt and road Initiative presents a systematic alternative against U.S. economic and financial dominance, the relative weakness of China and the belt and road Initiative per se may limit such potential. The lack of financial resources at the government level has undermined the effectiveness of China's infrastructure-driven investment. The reliance on private sector thus foreign financial market is always a potential backfire against Beijing's wishful thinking: developing economies may fail to repay the loans to the Chinese private sector thus creating an unhealthy credit crisis at domestic and private level, which is harmful to Chinese economic development; the Chinese over-expansion in developing economies, especially the transfer of loans to special rights in infrastructure projects, may induce economic nationalism in developing economies, undermining the political influence of the Belt and Road Initiative.

At a more structural level, the reliance on the financial sector also implies that China's infrastructure-driven economic diplomacy may not be a real systematic alternative, as the effectiveness of such economy still relies on the vibrant private financial sector which is still under the control of the United States. Indeed, if what Polanyi said is right and is applied to global capitalist system, the rise of China and the belt and road Initiative is merely a structural re-adjustment process predicted by the capitalist system, without fundamentally challenging the system as a whole. Of course, it is always possible that the system will remain with a different leader, yet it is still too early to determine which is which. 
Received: 14 August 2017 Accepted: 5 February 2018

Published online: 27 March 2018

\section{Notes}

1 Boog (2006) Quoting Alfred Jodl's "Strategic situation in spring 1944" presentation. The total given for German forces in the west in May 1944, prior to a slight upgrade of forces in the west in preparation for Operation Overlord, was 1,873,000 personnel. 2 Data retrieved from World Development Indicators.

\section{References}

Aberg JHS (2014) China's revisionist orientation. The Diplomat. http:// thediplomat.com/2014/09/chinas-revisionist-orientation/

Ansar A, Flyvbjerg B, Budzier A, Lunn D (2016) Does infrastructure investmentlead to economic growth or economic f ragility? Oxford Rev Econ Policy 32 (3):360-390

Arrighi G (1994) The Long Twentieth Century: Money, Power and the Origins of Our Times. Verso, London

Asian Development Bank (2017) Meeting Asia's Infrastructure Needs. Asian Development Bank, Philippines

Atkinson AB (2000) Increased Income Inquality in OECD Countries and the Redistributive Impact of the Government Budget. UNU World Institute for Development Economics Research Working Papers. No. 202

AT Kearney Inc (2013) Understanding the Needs and Consequences of Ageing Consumer. https://www.atkearney.com/documents/10192/682603/Understan ding + the + Needs + and + Consequences + of + the + Aging + Consumer.pdf/ $6 \mathrm{c} 2$ 5ffa3-0999-4b5c-8ff1-afdca0744fdc

Barston RP (2006) Modern diplomacy, 3rd edn. Pearson Longman, Harlow, p 73

Best W (2015) How Will Global Ageing Affect Consumer Spending? https://www. weforum.org/agenda/2015/01/how-will-global-ageing-affect-consumerspending/

Boog H, Krebs G, Vogel D (2006) Germany and the second world war. Vol 7. Clarendon Press, p 522

Carpenter TG (2013) China as a prickly, but pragmatic, Revisionist Power. https:// www.cato.org/publications/commentary/china-prickly-pragmatic-revisionistpower

Center for International Development at Harvard University (2003) Washington Consensus. http://www.cid.harvard.edu/cidtrade/issues/washington.html

Chen D (2014a) China's 'Marshall plan' is much more. http://thediplomat.com/ 2014/11/chinas-marshall-plan-is-much-more/

Chen D (2014b) Defining a 'New Type of Major Power Relations'. The Diplomat. http://thediplomat.com/2014/11/defining-a-new-type-of-major-powerrelations/

Curran E (2016) China's Marshall Plan. https:/www.bloomberg.com/news/articles/ 2016-08-07/china-s-marshall-plan

De Larrinage N (2016) French Army selects HK416 to replace FAMAS. http:// www.janes.com/article/64230/french-army-selects-hk416-to-replace-famas

Financial Times (2015) China’s Great Game: Road to a new empire. https://www.ft. com/content/6e098274-587a-11e5-a28b-50226830d644?mhq5j=e2

Frieden JA (2006) Dean Acheson, present at the creation. Global capitalism: its fall and rise in the twentieth century. pp 264-268

Glantz D (2005) Colossus reborn: the red army at war 1941-1943. University Press of Kansas, Kansas, pp 600-602

Gramer R (2017) Infographic: Here's How the Global GDP is Divvied Up. Foreign Policy. http://foreignpolicy.com/2017/02/24/infographic-heres-how-theglobal-gdp-is-divvied-up/

Groningen Growth and Development Centre (2014) Maddison project. http:// www.ggdc.net/maddison/maddison-project/home.htm

Harkavy R (2007) Strategic Basing and the Great Power. Routledge, London, New York

He L (2017) Private Finance Expected to Fill the Gap in Funding Asian Infrastructure Projects. SCMP. 6 July

HKTDC (2017) "The Visegrad Four (V4) Nations: Early Adopters of the Belt and Road Opportunity. http://economists-pick-research.hktdc.com/businessnews/article/\%E7\%A0\%94\%E7\%A9\%B6\%E6\%96\%87\%E7\%AB\%A0/V4\% E5\%9C\%8B\%E5\%AE\%B6-\%E7\%8E\%87\%E5\%85\%88\%E9\%96\%8B\%E6\%8B\% 93-\%E4\%B8\%80\%E5\%B8\%B6\%E4\%B8\%80\%E8\%B7\%AF-\%E6\%A9\%9F\% E9\%81\%87/rp/tc/1/1X32LK39/1X0AA60I.htm?utm_source=weky_edm\&utm_campaign=edm_promo_upd\&utm_medium=edm\&DCSext. dept $=12 \& W T . m c \_i d=6174451$

Jodl A (1944) Strategische Lage im Frühjahr 1944, Jodl, Vortrag 5.5. (BA-MA, N69/18.)

Kennedy P (1987) The (Relative) Decline of America. Atlantic Monthly. http:// aubel.free.fr/HIS/depuis_1945/monde/DOCS_dossier_doc_relat_internat_ dep_1945/Kennedy_1987/
Kennedy_Paul_The_Relative_Decline_of_America_The_Atlantic_Monthly_August_1987_p29-38.pdf

Ma CZ (2016) China’s One Belt, One Road: Will it reshape global trade? http:// www.mckinsey.com/global-themes/china/chinas-one-belt-one-road-will-itreshape-global-trade

Marantidou V (2014) Revisiting China's 'string of pearls' strategy: places 'with Chinese characteristics' and their security implications. Issues Insights 14(7): I-39

Modelski G (1987) Long Cycles in World Politic. Routledge, London

Modelski G, Thompson WR (1996). Leading Sectors and World Powers: The Coevolution of Global Economics and Politics. University of South Carolina Press, Columbia

Necrometrics (2013) Source List and Detailed Death Tolls for the Primary Megadeaths of the Twentieth Century. http://necrometrics.com/ $20 \mathrm{c} 5 \mathrm{~m} . \mathrm{htm}$

OECD (2013) Crisis Squeezes Income and Puts Pressure on Inquality and Poverty. http://www.oecd.org/els/soc/OECD2013-Inequality-and-Poverty-8p. pdf

Overmans R (2000) Deutsche militärische Verluste im Zweiten Weltkrieg. Oldenbourg, Muchen, p 336, p 174

Patton M (2016) U.S. Role in Global Economy Declines Nearly 50\%. https://www. forbes.com/sites/mikepatton/2016/02/29/u-s-role-in-global-economydeclines-nearly-50/\#2b04a7af5e9e

Polanyi K (1944) The Great Transformation: The Political and Economic Origins of Our Times. Beacon Press, Boston

Railway Gazette (2016) China backs Serbian railway modernisation. http://www. railwaygazette.com/news/infrastructure/single-view/view/china-backsserbian-railway-modernisation.html

Reference.com (2014) Who said 'the war to end all wars'? https://www.reference. com/history/said-war-end-wars-b98baf269539feb1

Sabine P (2017) Belt and road is 'Marshall Plan without a war', analysts say, as Beijing and banks woo private-sector investors. http://www.scmp.com/ special-reports/business/topics/one-belt-one-road/article/2082733/belt-androad-marshall-plan

Shen S (2016) How China's 'Belt and road' compares to the Marshall plan. http:// thediplomat.com/2016/02/how-chinas-belt-and-road-compares-to-themarshall-plan/

Singh A (2015) China's 'Maritime Bases' in the IOR: A Chronicle of Dominance Foretold. Strateg Anal 35(3):293-297

SIPRI (2017) SIPRI Military Expenditure Database. https://www.sipri.org/ databases/milex

Thompson WR (2001) The Emergence of the Global Political Economy. Routledge, London, New York

Wallerstein I (1984) The Politics of World Economy. Cambridge University Press, Cambridge

Williamson J (2002) What Washington Means by Policy Reform. https://piie.com/ commentary/speeches-papers/what-washington-means-policy-reform

Willoughby I (2017) Chinese trains giant CRRC to buy problem-hit Škoda Transportation? http://www.radio.cz/en/section/business/chinese-trainsgiant-crrc-to-buy-problem-hit-skoda-transportation

Zeng J (2016) Constructing a "New Type of Great Power Relations": the State of Debate in China (1998-2014) British J Polit Int Relat 18 (2):422-442

Zhang JJ (2011) Seeking the Beijing Consensus in Asia: An Empirical Test of Soft Power. https://dukespace.lib.duke.edu/dspace/bitstream/handle/10161/5383/ Duke\%20Honors\%20Thesis.pdf?sequence=1, https://www.ft.com/content/ 9312e100-f71c-11e5-803c-d27c7117d132?mhq5j=e3

\section{Data availability}

Data sharing is not applicable to this article as no datasets were generated or analyzed during the current study.

\section{Acknowledgements}

The authors would like to express their sincere thanks to Mr. Justin Lau and Mr. Eugene Lo for their support on the draft of the paper.

\section{Additional information}

Competing interests: Professor Simon Shen's work was funded by Hong Kong Policy Research Institute's International Relations Research Centre. Mr Wilson Chan declares no competing financial interests.

Reprints and permission information is available online at http://www.nature.com/ reprints

Publisher's note: Springer Nature remains neutral with regard to jurisdictional claims in published maps and institutional affiliations. 
(c) (i) Open Access This article is licensed under a Creative Commons C. Attribution 4.0 International License, which permits use, sharing, adaptation, distribution and reproduction in any medium or format, as long as you give appropriate credit to the original author(s) and the source, provide a link to the Creative Commons license, and indicate if changes were made. The images or other third party material in this article are included in the article's Creative Commons license, unless indicated otherwise in a credit line to the material. If material is not included in the article's Creative Commons license and your intended use is not permitted by statutory regulation or exceeds the permitted use, you will need to obtain permission directly from the copyright holder. To view a copy of this license, visit http://creativecommons.org/ licenses/by/4.0/.

(C) The Author(s) 2018 